\title{
SPOTKANIA POETÓW W PRZESTRZENI I W SŁOWIE - O WIERSZACH NORWIDA DO JÓZEFA BOHDANA ZALESKIEGO
}

Jeżeli szukać na mapie takich miejsc spotkań polskich romantyków, które pozostawiły trwały ślad w ich biografiach i dziełach, to przestrzeń Rzymu jest jednym z najważniejszych. To tutaj wiosną 1836 roku Juliusz Słowacki poznał Zygmunta Krasińskiego, a toczone wśród ruin i ogrodów dyskusje otworzyły jedną z ważniejszych linii poetyckiego i ideowego sporu tamtej epoki. To tutaj w 1848 roku Cyprian Norwid gościł w swojej pracowni na Via Sistina Zygmunta Krasińskiego, to w Wiecznym Mieście poznał osobiście Adama Mickiewicza i Stefana Witwickiego. I także tutaj spotkał Józefa Bohdana Zaleskiego, co stało się początkiem wieloletniej przyjaźni, której literackim śladem jest spory blok korespondencji ${ }^{1}$ i dwa wiersze Norwida: pierwszy, napisany na początku znajomości, zatytułowany Do Józefa Bohdana Zaleskiego w Rzymie 1847-o, drugi - powstały pięć lat później. Odwracając chronologiczny porządek, zacznę od refleksji nad tym drugim, bo to uwagi o nim stanowią kompozycyjną klamrę tego szkicu.

Tytuł wiersza Na przyjazd Teofila Lenartowicza do Fontainbleau sugeruje, że mamy oto do czynienia z okolicznościowym drobiazgiem wystylizowanym wedle klasycystycznego wzoru, napisanym być może z pastiszowym zamysłem. Przy uważniejszej lekturze okazuje się jednak, że wiersz niespodziewanie otwiera znacznie szersze pole widzenia na lirykę romantyczną, niż mogłaby na to wskazywać tytułowa formuła. Sytuacja liryczna wiąże się z paryskim spotkaniem trzech polskich poetów-emigrantów, należących do dwóch różnych romantycznych ge-

${ }^{1}$ Norwid szczególnie intensywnie korespondował z Zaleskim w latach: 1847-1852 ; na ten okres przypada blisko połowa $\mathrm{z}$ całego bloku obejmującego 63 listy do tego adresata. Wymiana korespondencji, wznowionej w 1856, roku trwała do końca życia; ostatni list do poety napisał Norwid 5 grudnia 1882 r. Zob. DW X-XII, PWsz VIII-X. 
neracji: Józefa Bohdana Zaleskiego (1802-1886) i młodszych o pokolenie: Teofila Lenartowicza i autora wiersza - Cypriana Norwida. To spotkanie wydarzyło się naprawdę w połowie XIX stulecia i było w różny sposób uwikłane w biografie jego uczestników, których życiowe i artystyczne drogi zbiegały się już wcześniej, a wzajemne relacje miały swoją historię.

Przyjrzyjmy się najpierw okolicznościom powstania wiersza. Po latach w kwietniu 1886 roku, na prośbę Adama Pługa, Lenartowicz spisał swoje wspomnienia o Zaleskim ${ }^{2}$. Epizod związany z Norwidowską rekomendacją przywoływał tam dosyć obszernie, wspominając czas, gdy znalazł się nad Sekwaną, „sam, bez niczyjej opieki [...]”, a wówczas, jak wspominał:

Cyprian Norwid, który mi służył za Kornaka w Paryżu - raz szalenie pyszny, raz dobry jak anioł, czuły i pełen serca, kiedym mu o zamierzonej podróży do Fontainbleau powiedział, zapewnił mnie: że z jego listem będę dobrze przyjęty i siadłszy przed sztalugą, na której znajdował się karton jego pomysłu, począł pisać wiersz rekomendujący do Bohdana, którego nie oddałem i do dziś dnia przechowuję",

Lenartowicz przyjechał do Paryża z Brukseli w końcu czerwca lub w pierwszych dniach lipca 1852 roku i gdy dowiedział się, że Zaleski mieszka w podparyskiej miejscowości, zapragnął osobiście poznać poetę, którego uznawał i za swojego mistrza, i za drugiego po Mickiewiczu romantycznego wieszcza, a ta ostatnia opinia nie była wówczas odosobniona.

Widziałem już Adama, małym dzieckiem widziałem Brodzińskiego, potem Jenerała Morawskiego, niechże teraz zobaczę autora dumki o Rusłanie, a dosięgnę szczytu szczęścia... ${ }^{4}$

I latem 1852 marzenie się spełniło.

Z tym splotem epizodów z życia trzech poetów wiążą się pytania, na które odpowiedzi rozświetlają nieco kontekst i edytorskie dzieje utworu: Dlaczego Norwid uważał, że jego rekomendacja wpłynie na serdeczne przyjęcie polecanego gościa? Czy rzeczywiście napisał wiersz spontanicznie, odrywając się na chwilę od malarskich zatrudnień? I wreszcie - dlaczego Lenartowicz nie pokazał tego listu poetyckiego adresatowi?

Autora wiersza łączyły ze starszym poetą znaczące dla obydwu rzymskie wspomnienia. Norwid poznał Bohdana i Zofię Zaleskich latem 1847 roku w Rzy-

2 Zostały opublikowane w „Kłosach” (nr 1091, maj 1886).

3 Tamże, s. 332; zob. także: PWsz XI, 474 oraz Z. Trojanowiczowa, Z. DAMBEK przy współudziale J. Czarnomorskiej, Kalendarz życia i twórczości Cypriana Norwida, t. I: 1821-1860, Poznań 2007, s. 501-502.

${ }^{4}$ T. Lenartowicz, Wspomnienie o Bohdanie Zaleskim, „Kłosy” (patrz przypis 2). 
mie, gdzie małżonkowie dotarli w trakcie swojej pierwszej wspólnej, europejskiej podróży ${ }^{5}$. Lipcowe wędrówki po Wiecznym Mieście w towarzystwie Norwida - zwłaszcza, wspominany później z nostalgią w listach, spacer do Koloseum - rozmowy o historii, religii, poezji i polityce okazały się początkiem przyjaźni. Łączyły poetów: religijna wrażliwość, zainteresowanie rzymskimi początkami chrześcijaństwa, jego prześladowaniem i późniejszym przenikaniem na obszary słowiańskie, zbliżone oceny sytuacji politycznej w Europie, krytycyzm wobec emigracyjnej działalności Andrzeja Towiańskiego ${ }^{6}$. Zaleski stał się niebawem powiernikiem Norwida; to jemu młodszy poeta powierzył rękopis Wan$d y$, prosząc o pomoc w wydaniu dramatu, to z listów do niego dowiadujemy się o pracy nad następnym (zaginionym) utworem dramatycznym pt. Patkul i o koncepcji malarskiego dzieła, nazywanego w korespondencji ,wizją nakolizejską"? Już początek przyjaźni z Zaleskimi znalazł wyraz w dwóch wierszach Norwida: Do Józefa Bohdana Zaleskiego w Rzymie 1847-o oraz w 'legendzie" ${ }^{8}$ pt. Amen, z takimi słowami ofiarowanej żonie poety: „Pani Zofii Zaleskiej od współ-Mazura (po kądzieli)”. Dedykacja subtelnie podkreśla rodowodową i pokoleniową więź z adresatką. Zofia z Rosengardtów Zaleska była rówieśniczką Lenartowicza (ur. w 1822 roku), warszawianką, uczennicą Fryderyka Chopina. Ukształtowała ją romantyczna Warszawa i melancholia Mazowsza - podobnie jak Fryderyka, Cypriana, Teofila. Obydwaj młodsi poeci, zwłaszcza Lenartowicz, będą później podkreślać ślady obyczaju i serdeczności mazowieckiego dworku przeniesione do domu Zaleskich w podparyskim Fontainbleau. Nawiasowe wtrącenie w Norwidowskiej dedykacji niesie też coś jeszcze - przypomnienie matki ${ }^{9}$. W trudnym okresie paryskim, poprzedzającym wyjazd do Ameryki Północnej, Norwid często znajdował wsparcie i rodzinne ciepło u poznanych w Rzymie przyjaciół. Gdy więc właśnie w tamtym czasie polecał życzliwości gospodarzy domu w Fonta-

${ }^{5}$ Zalescy wzięli ślub 26 listopada 1846, podróż włoska była ich przesuniętą w czasie podróżą poślubną. W Rzymie i okolicach spędzili prawie całe lato 1847.

${ }^{6}$ Zob. B. StelmaSzCZYK-Świontek, Wstęp w: J. B. ZALESKi, Wybór poezyj, Wrocław - Łódź 1985, BN I, nr 30.

7 Zob. listy do J. B. Zaleskiego z 1852 r.

${ }^{8}$ Taka kwalifikacja gatunkowa zawarta w podtytule wiersza częściej pojawia się w Norwidowskiej liryce, a nawiązuje do średniowiecznej, ,klasztornej” semantyki słowa 'legenda' (od łac. legere - 'czytać'); podczas niektórych nabożeństw oraz w czasie posiłków w refektarzach klasztornych lektor czytał ustępy z Pisma św. lub fragmenty żywotów świętych, a ta lektura była nosiła nazwę 'legendy'.

${ }^{9}$ Ludwika ze Zdzieborskich Norwidowa, spokrewniona z Dybowskimi i Sobieskimi, urodziła się i wychowała na Mazowszu. Zmarła w 1825, osierociła czworo małych dzieci; Cyprian miał wówczas 4 lata. 
inbleau artystę i swojego przyjaciela z czasów warszawskich, wiedział zapewne, że ta rekomendacja spotęguje ich serdeczność i Lenartowicz „będzie z tym listem dobrze przyjęty".

Analiza rękopisu ${ }^{10}$ wiersza pozwala przyjąć ostrożnie hipotezę o jego spontanicznym, pospiesznym pisaniu; przemawiają za nią poprawki i skreślenia. Pozostaje jednak edytorską zagadką, kto i kiedy ich dokonał. Zenon Przesmycki przypuszczał, że najprawdopodobniej zrobił to Lenartowicz: „Niepodobna przypuścić, aby Norwid, dając przyjacielowi poetycki list polecający, wymazywał coś w nim [...]. Lenartowiczowi zaś, po dokonaniu operacji, niejako było wręczyć adresatowi rekomendację z wykreśleniami - i dlatego właśnie, nie zaś, jak sam twierdzi, dla niezasłużonych pochwał - zachował ją sobie." ${ }^{11}$ Przypuszczenie edytora może być trafne, co nie znaczy, że pewne. Możliwe, że Lenartowicz wykreślił strofy 5, 6 i 7 na przykład dlatego, że w tym fragmencie były już naniesione drobniejsze poprawki autorskie Norwida i rzecz nie wyglądała na czystopis, a może zrobił to w ramach korekty wiersza dopiero wtedy, gdy przesyłał utwór do lwowskiej „Strzechy”, gdzie tekst został opublikowany w skróconej wersji i bez podziału na wyodrębnione w autografie części. Tego już jednoznacznie nie rozstrzygniemy i nie odczytamy też w całości wykreślonych 12 wersów. Poniżej zamieszczam własne edytorskie opracowanie tekstu wiersza przygotowane na podstawie Norwidowskiego rękopisu, zaznaczając również wszystkie nie odczytane w autografie miejsca w wersach: $20-26$.

\section{NA PRZYJAZD TEOFILA LENARTOWICZA DO FONTAINEBLEAU}

Złoto-struny! - albo ja wiem,

Jak pisać do Ciebie?

Choćbym pisał piórem pawiém

Umaczanym w niebie

5 I to mało!...

${ }^{10}$ Autograf wiersza znajduje się w albumie Lenartowicza Umarli żywi i jest przechowywany w Bibliotece PAU w Krakowie (sygn.. 2029, k. 75 recto i verso), opatrzony został podpisem Cyprjan i datą 1852. W 1871 roku lwowska „Strzecha” opublikowała kilka wierszy Lenartowicza wybranych przez poetę z tego albumu, między innymi - analizowany, z pominięciem fragmentów, które zostały w autografie skreślone. Nic jednak nie wskazuje na to, że Norwid wiedział o tej edycji, a tym bardziej, że dokonał jej autorskiej korekty.

11 Z. Przesmycki, Wstęp, w: C. Norwid, Reszta wierszy do dziś odszukanych, oprac. Z. Przesmycki, Warszawa 1933, s. VII. 
Jedwabniejsze piór powianie,

Błękitniejsze znasz otchłanie

Z gwiazdą białą!...

To - napiszę-ć ja bogaciéj

${ }^{10}$ Posłem dobrym -

Jednym z młodszych Twoich braci

Kornie-chrobrym...

Gdzieś go znałeś za-tym-znaniem

Lub nad-znaniem tym;

${ }^{15} \mathrm{Za}$ tym czasów-urąganiem,

Co nie dzwoni w rym.

Za tym dzikim zgrzytem dłuta,

Co odpryska w pył;

Ale za to postać kuta

${ }^{20}[\ldots . . ?]$ tyleś żył!"

Za tym jawem, który noca

Blizna, [...?? jest $[<z n a k>$ ?];

Za nieznaną tą wszechmocą,

Którą kocham tak!...

${ }^{25}$ Za tym [ $<$ jadem a $>$ ?] miłością

Poplątaną [....?] -

Za tą (mówię) realnością,

Którą gardzę tak! 
Lepiej, że on w Fonteneblo

${ }^{30} \mathrm{Niż} \mathrm{ja}$ - dzikie ptasze;

Bo strzeliściej się ze-szczeblą

Pogadanki Wasze...

Jak orzechu strojną perłą

$\mathrm{Z}$ wiatrem igra leszcz,

35 Takie pieśni jego berło,

Taki to on wieszcz.

A tak śpiewny, że aż śpiewam,

Dobry, że aż żal

Czysty, że aż się spodziewam.

${ }^{40}$ Szczery - że choć chwal!

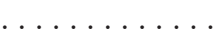

III

Niech Marianka on uściśnie,

Pannie - kwiat zaniesie

I czerwone z Wami wiśnie

Je - i chodzi w lesie.

1852

Dotychczasowe wzmianki o przyjaźni Zaleskiego z Norwidem akcentowały harmonię zainteresowań i poglądów obydwu poetów. Była to jednak tylko jedna strona ich wzajemnej relacji. ${ }^{12} \mathrm{O}$ tym, że różniło ich spojrzenie na poezję i liryczna dykcja, i że Norwid przenikliwie to dostrzegał, świadczył już rzymski wiersz, dedykowany „ukraińskiemu lirnikowi”. Osią kompozycyjną tego utworu jest wie-

12 Wielostronną analizę relacji obu poetów, wychodzącą od podobieństw i różnic pokoleniowych, przedstawiła Elżbieta NowicKa w studium: Cyprian Norwid i Józef Bohdan Zaleski, czyli to, co wspólne między pokoleniami, w: O Norwidzie komparatystycznie, red. M. Siwiec, Kraków 2019, s. 179-206. 
lopoziomowy kontrast między lirycznym, odautorskim ,ja” a lirycznym „ty” jednoznacznie skojarzonym z osobą i twórczością adresata wiersza.

\title{
DO JÓZEFA BOHDANA ZALESKIEGO
}

\author{
W RZYMIE \\ 1847-o
}

1

Dobrze tęczy się zielenić, Błękitnawić i czerwienić, Tej Wielmożnej Pani!...

Ale, chmurki oddalone

5 By jagnięta pogubione, $\mathrm{Te}$ - kto chce, to gani.

2

Ej - i z lutnią złoto-runą,

Złoto-ustą, siedmiostruną

Nieba obiec sklepy.

$10 \quad$ Lżej - niż piosnkę raz zaczętą

Już we fletnię dąć pękniętą

Jak włóczęga ślepy.

3

Tyś bo wiele odziedziczył,

Tyś bo panie zagraniczył

${ }^{15} \mathrm{Z}$ niebem - mogiłami;

Więc to Seraf, to Cherubin

Niby wisien spadnie rubin

W ogród twój - skrzydłami.

4

A jam chłopię zza ogrodu

${ }^{20}$ Gdzieś u szpary drżące wchodu,

Gości - strach mnie bierze:

I strach ciebie, pana sadu

Co tam z duchy gadu, gadu, Jak dzwon na pacierze... 
5

25 A jam chłopię z dróg krzyżowych,

Zza trzęsawisk olszynowych,

Gdzie mdłe jęczą cienie -

I głód zemsty w sercu u mnie

Już wyrodził się jak w trumnie

30 Chude lisa szczenię.

6

I wiatr zabrał mię w powicie

Chmur - by nagle zmarłe dziécię

Bez chrztu-krwie i walki...

Tu, na cmentarz poniósł ludów,

35 Gdzie trzy świecą panie-cudów -

Gdzie sztuki - Westalki...

7

Gdzie krzyż z włócznią w jednej dłoni,

$\mathrm{Z}$ gąbką w drugiej - z cierniem w skroni,

Księżyc ma nad sobą;

40 I kompasu wodząc cienie

Po otartej z krwi Arenie

Cieszy nas żałobą.

8

- Kiedyż czasów wypełnienie, Kiedyż Polski odkupienie?! -

${ }^{45}$ Wieszczym zanuć słowem:

A sto wiatrów je rozniesie

Precz po lesie, za po-lesie

Po echu stepowém... ${ }^{13}$

Odmienność sytuacji adresata i podmiotu zapowiada już obraz nieba, stanowiący inne tło dla każdego z nich. Niebo pierwszego mieni się kolorami tęczy, niebo drugiego znaczą obłoki targane wiatrem. Symbolicznym atrybutem poezji

13 Tekst wiersza podaję we własnym opracowaniu edytorskim, przygotowanym do edycji I tomu Dzieł wszystkich C. Norwida. 
pierwszego jest „złoto-runa lutnia”, drugiego - „pęknięta fletnia”. Tęcza i lutnia oraz królewskie kolory dominujące w poetyckim obrazowaniu (złoto, czerwień, błękit) przygotowują kulminację pierwszej części utworu - wejście „pana sadu” do swojego gospodarstwa. Symbolika kolorów wskazuje na pokrewieństwo z tradycją wschodnich ikon, a zarazem nawiązuje do śladów bizantyjsko-chrześcijańskiej ikonosfery w poetyckim obrazowaniu Zaleskiego ${ }^{14}$. Quasi-rajska przestrzeń łącząca cechy ogrodu i sadu - sielankowa synteza kwitnienia i owocowania - nie ogranicza się jednak do swojego horyzontalnego wymiaru; jest otwarta i w górę (ku aniołom), i w dół (ku mogiłom). Zapowiada wgląd w niewidzialne, otwiera na transcendencję. To wertykalne otwarcie zapowiadał już na wstępie motyw tęczy, wnoszący biblijną symbolikę przymierza Boga z człowiekiem. Plastyczny nadmiar kolorów oraz motywów i w konsekwencji - przerysowana idealizacja przestrzeni i sytuacji niesie tutaj ironiczne sugestie, tylko lekko osłabione aluzją do heroicznych czynów adresata (motyw „chrztu krwi”) ${ }^{15}$. Podmiot jest natomiast prezentowany jako drżący chłopiec, ślepy włóczęga. Tak zarysowana kondycja tylko pozornie deprecjonuje tę postać. Wskazuje bowiem z jednej strony na tradycję starożytnych rapsodów, z drugiej - na wątek ukraińskich lirników przemierzających stepowe przestrzenie. Czerpie więc i z archiwum poetyckich motywów eposu, i z motywiki „szkoły ukraińskiej”, charakterystycznej zresztą nie tylko dla Zaleskiego ${ }^{16}$. Dziecko, które nie śmie przekroczyć bram ogrodu i wyłania się ze zdegradowanego, mrocznego pejzażu otrzymuje cechy tajemniczego Pacholęcia z Marii Malczewskiego i ma coś z antycznej tradycji natchnionych śpiewaków. Jego domeny nie stanowi jednak step, lecz „drogi krzyżowe” i „olszynowe" trzęsawiska zbiorowych cierpień. To już echa romantyzmu polistopadowego, w których pobrzmiewa ton z wizji księdza Piotra w Mickiewiczowskich Dziadach drezdeńskich, ale zarazem, tak jak u Malczewskiego, otwarcie na wertykalny i transcendentny wymiar przestrzeni wcale nie jest oczywiste. Można tę postać odczytać jako poetycką figurę „młodej emigracji” - pokolenia Norwida, w imie-

${ }^{14}$ Zob. O. Krysowski, Motywy bizantyjsko-chrześcijańskie w poezji Józefa Bohdana Zaleskiego, w: ,Szkoła ukraińska” w romantyzmie polskim, red. St. Makowski, U. Makowska, M. Nesteruk, Warszawa 2012, s. 81-94.

15 Jest to prawdopodobnie aluzja do powstańczych czynów Zaleskiego, uczestnika bitwy o Olszynkę Grochowską w lutym 1831 roku, odznaczonego za bohaterstwo krzyżem Virtuti Militari.

${ }^{16}$ Wprawdzie intertekstualna gra z utworami Zaleskiego jest na pierwszym planie, ponieważ podkreśla ją mocno wersyfikacja i instrumentacja wiersza nawiązująca do charakterystycznej dla autora Rusałek formy ośmiozgłoskowca, z przewagą rymów przyległych. Zob. L. PszczoŁOWSKA, O wierszu ,, słowika ukraińskiego”, w: ,Szkoła ukraińska” w romantyzmie polskim, s. $35-52$. 
niu którego poeta miał wkrótce przemówić pełniejszym głosem ${ }^{17}$. I ci dwaj tak różni: „pan sadu” i drżący chłopiec, spotykają się pod krzyżem w rzymskim Koloseum. Młodszy stawia pytanie o wieszcze słowo, które odsłoni być może sens zbiorowego losu. Domagając się odpowiedzi, sugeruje jednak, że dotąd ona jeszcze nie padła i ujawnia cień zwątpienia w poznawczą moc wieszczej poezji, obecny mimo uznania dla jej zniewalającego piękna.

Jedną z możliwych symbolicznych wykładni motywu ogrodu/sadu jest odczytanie go jako symbolu polskiej poezji romantycznej. Reprezentant młodego pokolenia i zarazem porte parole autora staje przed wejściem w ten poetycki świat $\mathrm{z}$ lękiem i wahaniem. $Z$ jednej strony przerasta go on swoją wspaniałością, z drugiej - czuje, że nie jest już jego światem, ale innego, w którym mógłby się zadomowić, na razie nie ma. Wiersz zawiesza pytanie o możliwość założenia i uprawy innego „ogrodu”, ale zarazem sugeruje, że bardziej prawdopodobna jest ciągła tułaczka bez takiego zakorzenienia. Podmiot wiersza staje na rozdrożu - nie chce być prostodusznym spadkobiercą zastanego dziedzictwa, ale odmienna droga nie zarysowała się jeszcze jasno. Szuka jej więc u źródła - pod krzyżem w rzymskim Koloseum, w towarzystwie wieszcza i współtwórcy romantycznego pejzażu polskiej kultury, ale jak gdyby obok niego, a nie razem z nim. Zarazem jednak przestrzeń areny z centralnie umieszczonym na niej krzyżem, przypominającym sens męczeństwa Chrystusa i męczenników, którzy podążali jego śladami, łączy obu poetów i staje się pomostem między romantycznymi pokoleniami.

Czy w wierszu napisanym pięć lat później można odnaleźć jakiś dalszy ciąg zawieszonego dialogu poetów? Już inicjalne pytanie wydaje się na to wskazywać, a epitet „złoto-struny”, którym poeta określa adresata, można odczytać jako autoaluzję do utworu z 1847 roku. Delikatność, bogactwo kolorów i śpiewność - sugerowaną wersyfikacyjnymi wariacjami na temat ośmiozgłoskowca i dokładnością prostych rymów - Norwid nadal wskazuje jako dominujące cechy poetyki Zaleskiego. Demonstruje, że owszem - taki warsztat liryczny nie jest mu obcy, dowiódł tego zresztą wcześniej jako autor Częstochowskich wierszy, ale zarazem ten styl pozostanie dla niego zewnętrzną szatą, sposobem stylizacji obojętnym wobec wewnętrznej, podmiotowej prawdy. Wyznanie w pierwszej strofie, wzmocnione wykrzyknikiem, akcentuje już na początku tę autorską świadomość („Choćbym pisał piórem pawiém/ Umaczanym w niebie/ I to mało!...”). Zarazem staje się ono punktem wyjścia kunsztownego konceptu kreującego sytuację liryczną. Ma on kształt składniowego neologizmu i zarazem anakolutu: „To - napiszę-ć ja bogaciej/ Posłem dobrym - ". Jeśli rozwikłać semantykę wstępnego

${ }^{17}$ Przede wszystkim w dramacie Zwolon i artykułach publikowanych w krakowskim „Czasie" (Listy o Emigracji). 
fragmentu, to można ją zrekonstruować tak: - Wprawdzie moja poezja nie harmonizuje $\mathrm{z}$ twoją i jest $\mathrm{z}$ innej poetyckiej krainy, ale posyłam ci mego przyjaciela, który jest żywym słowem do ciebie, bardziej korespondującym z twoim. Być może Lenartowicz właśnie ze względu na ten koncept nie oddał listu poetyckiego Zaleskiemu, bo poczuł się, mimo pochwał w dalszych strofach, instrumentalnie zredukowany. Tego przypuszczenia nie sposób zweryfikować, ale jeśli wziąć pod uwagę korespondencyjne i liryczne napięcia pojawiające się w różnych okresach we wzajemnych relacjach Norwida i Lenartowicza, jest ono oparte na istotnych przesłankach ${ }^{18}$.

Zanim Norwid przejdzie do prezentacji i rekomendacji gościa, kolejne strofy poświęci refleksji o tajemniczej więzi łączącej muzę Zaleskiego i Lenartowicza, o współbrzmieniu ich poezji i jego tajemniczych źródłach. Chociaż obydwaj jego przyjaciele nie znali się jeszcze osobiście w czasie, gdy pisał ten poetycki list, dostrzegł istnienie między nimi duchowego pokrewieństwa, jakiejś przedustawnej wspólnoty odczuwania, której źródła umieszcza ,za-tym-znaniem/ Lub nad-znaniem”. Przyimek ,nad” wskazuje na niedostępną człowiekowi Bożą perspektywę i do niej poeta nie próbuje dotrzeć, natomiast przyimek „za” odnosi się do ludzkiego poznania i ten aspekt autor wiersza stara się rozszyfrować. Aż czterokrotnie pojawia się anafora „Za tym...” otwierająca kolejne strofy. Wysiłek poetyckiej refleksji skupia się zatem na wskazaniu zasłon przesłaniających poznanie. Niestety, tutaj moja interpretacja potyka się o tekstologiczną aporię, bo wspomniana anafora to inicjalne słowa $\mathrm{w}$ trzech kolejnych pokreślonych zwrotkach (wersy 17-29), które można odczytać tylko częściowo, a więc i interpretacyjne uwagi trzeba opatrywać znakiem zapytania ${ }^{19}$.

Pierwsze użycie anafory (w wersie 15) jest czytelne. Można tę strofę rozumieć jako sugestię, że poznanie przesłania ludzka percepcja czasu, rejestrująca w potocznym doświadczeniu jego chaotyczny, dysonansowy charakter, co zakrywa wewnętrzną harmonię i boski ład jego biegu ${ }^{20}$. Rzeźbiarska metafora ${ }^{21} \mathrm{w}$ piątej strofie, w której ostatni wers jest nie do zrekonstruowania, przestrzega być może przed

18 Zob. Z. Szmydtowa, Norwid i Lenartowicz, „Przegląd Humanistyczny” 1973, nr 1; J. FerT, Norwid-poeta dialogu, Wrocław 1982; M. Adamiec, Oni i Norwid, Wrocław 1991.

${ }^{19}$ Hipotetycznie przyjmuję, po oględzinach autografu, że nad skreśleniami pracowali obydwaj poeci: Norwid, który zmagał się z „,daniem rzeczy odpowiedniego słowa”, a później - Lenartowicz, który wykreślił zwrotki z autorskimi poprawkami, dążąc do nadania wierszowi większej spójności.

20 Zob. np. M. Szulakiewicz, Czas i to, co ludzkie. Szkice z chronozofii kultury, Toruń 2011.

${ }^{21}$ Motywy rzeźbiarskie w poezji Norwida wielokrotnie przyciągały uwagę interpretatorów.; zob. np. K. WYKa, Cyprian Norwid. Poeta i sztukmistrz, Kraków 1948; G. KróLIKIEwICZ, Terytorium ruin, Kraków 1993; S. SAwICKI, Wstęp, w: C. Norwid, Promethidion, Kraków 1997, „Biblioteka Polska"; D. PNIEwsKi, Między obrazem a słowem, Lublin 2005. 
tym, że wysiłek („dziki zgrzyt dłuta”) bez pamięci o celu (kształcie posągu) oddala od uchwycenia sensu i istoty dzieła, od jego rozumienia. Jeszcze słabiej czytelna kolejna zwrotka być może upomina się o prawdę snów i marzeń, którą zaciera ekspansywna jawa. Ostatnia z pokreślonych strof akcentuje, jak można się domyślać zestawiając poszczególne słowa, poznawczy aspekt miłości, a może w ogóle-uczuć.

W II. i III. części, na którą składa się tylko jeden czterowiersz, autor zawiesza poznawcze zmagania podmiotu, powraca do konwencji poetyckiego listu rekomendacyjnego i zdaje się wskazywać, że jego intelektualne rozterki są mało istotne, bo „pogadanki” adresata i bohatera wiersza „ze-szczeblą” się harmonijnie bez takiego pośrednictwa i bez wysiłku spotkają się oni w poetyckim słowie. Dokona się to przede wszystkim dzięki temu, że ich pieśni są jak gdyby przedłużeniem pieśni natury, na co wskazuje porównanie liryki Lenartowicza do „muzy-

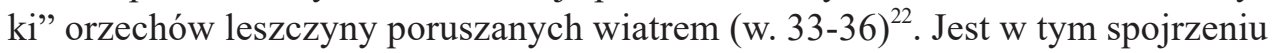
echo myśli Schellinga, spopularyzowanej w polskiej krytyce romantycznej przez Maurycego Mochnackiego i Seweryna Goszczyńskiego ${ }^{23}$, dostrzegającej korespondencję między nieskończoną poezją natury i poezją-sztuką słowa, która objawia tę pierwszą, chociaż nie ogarnie nigdy jej nieskończoności.

Pochwała Lenartowicza w przedostatniej strofie ewokuje jeszcze inną przyczynę jego duchowej bliskości z Zaleskim. Spośród epitetów, które się na nią składają: ,śpiewny, dobry, czysty, szczery”, tylko pierwszy odnosi się do jakości estetycznej; pozostałe wskazują na wartości moralne. Wyodrębnienie takich przymiotów bohatera lirycznego sugeruje, że źródłem płynności i harmonii jego pieśni jest egzystencjalny ład i pogoda ducha pozwalająca go dostrzegać i kształtować. Taka postawa prowadzi ku „pieśni pokornej”, jak w innym miejscu określił Norwid lirykę Lenartowicza ${ }^{24}$. Pokora wynika $\mathrm{z}$ akceptacji swojego miejsca w uniwersum istnienia i duchowego związku z naturą. I Zaleski, i Lenartowicz są w interpretacji Norwida bliscy bieguna poezji naiwnej - rozumianej tak, jak rozumiał to Fryderyk Schiller, wprowadzając rozróżnienie postaw: poety naiwnego

22 Jest to poetycko niezbyt udany fragment, ze względu na derywację: leszczyna/leszcz - tak, by skrócone słowo rymowało się ze słowem wieszcz.

${ }^{23}$ Zwłaszcza Goszczyński podkreślał podział na ,poezję natury”, której twórcą jest Bóg i ,poezję-sztukę" stanowiącą cząstkę uniwersum panpoezji. Zob. S. Goszczyński, Nowa epoka poezji polskiej, 1835; szerzej pisałam na ten temat w artykule: Liryczność a poznawcze aspiracje podmiotu. Przyczynek do romantycznego kontekstu zagadnienia, w: Liryczność, red. B. Kuczera-Chachulska, E. Skalińska, Warszawa 2013.

${ }^{24}$ C. NorwID, [Ty mnie do pieśni pokornej nie wołaj...], w: tenże, Dzieła zebrane, Wiersze, t. I, oprac. J. W. Gomulicki, Warszawa 1966, s. 365. 
i sentymentalnego $0^{25}$. Autor wiersza, z wyostrzoną świadomością dysonansów istnienia i braku dróg do Arkadii, jest bliższy wzoru drugiej postawy. Nie przeciwstawia jednak tak mocno, jak we wcześniejszym wierszu do Zaleskiego, swojego doświadczenia - doświadczeniu przyjaciół. Delikatniej akcentuje odmienność własnej postawy poetyckiej i nie łączy jej z sytuacją pokolenia. Dostrzega, że Lenartowicz należy przecież do tej samej generacji, a bliższy jest mu wzór bycia poetą ukształtowany przez poprzedników. W emocjonalnym tonie wiersza można odnaleźć ślad Norwidowskiej melancholii, wynikającej ze świadomości, że od prostej radości istnienia coś go nieodwołalnie oddziela. Czy na drodze do poetyckiej dojrzałości późnych wierszy - tych z Vade-mecumi dalej - liryczny namysł nad poetyckimi postawami Zaleskiego i Lenartowicza był dla autora wierszy ważny, a jeżeli tak - to w jakim stopniu? W świetle interpretowanych utworów można dostrzec, że był jednym z impulsów pozwalających dookreślić własną odrębność i pogłębić artystyczną samoświadomość. Jak widać, nie tylko dzieła romantycznych „wielkoludów” stanowiły istotne punkty odniesienia na Norwidowskiej drodze do artystycznych spełnień.

\section{BIBLIOGRAFIA}

Adamiec M., Oni i Norwid, Wrocław 1991.

FERT J. F., Norwid - poeta dialogu, Wrocław 1982.

Goszczý́ski S., Nowa epoka poezji polskiej, „Powszechny Pamiętnik Nauk i Umiejętności” Kraków 1835 (artykuł ogłoszony anonimowo).

Halkiewicz-SojaK G., Liryczność a poznawcze aspiracje podmiotu. Przyczynek do romantycznego kontekstu zagadnienia, w: Liryczność, red. B. Kuczera-Chachulska, E. Skalińska, Warszawa 2013, s. 61-72.

KRYsowsKi O., Motywy bizantyjsko-chrześcijańskie w poezji Józefa Bohdana Zaleskiego, w: „Szkoła ukraińska” w romantyzmie polskim, red. St. Makowski, U. Makowska, M. Nesteruk, Warszawa 2012, s. 81-94,

Lenartowicz T., Umarli żywi, atg Bibl. PAU w Krakowie, sygn. 2029.

LeNartowicz T., Wspomnienie o Bohdanie Zaleskim, „Kłosy” 1886, nr 1091.

Nowicka E., Cyprian Norwid i Józef Bohdan Zaleski, czyli to, co wspólne między pokoleniami, w: O Norwidzie komparatystycznie, red. M. Siwiec, Kraków 2019, s. 179-206.

PRZeSmycki Z. (Miriam), Wstęp, w: Reszta wierszy do dziś odszukanych, Warszawa 1933.

Pszczolowska L., O wierszu ,stowika ukraińskiego”, w: „Szkoła ukraińska” w romantyzmie polskim, w: „Szkoła ukraińska” w romantyzmie polskim, red. St. Makowski, U. Makowska, M. Nesteruk, Warszawa 2012, s. 35-52.

SAwicki S., Wstęp w: C. Norwid, Promethidion, Kraków 1997, „Biblioteka Polska”.

${ }_{25}$ Zob. F. SCHILLER, O poezji naiwnej i sentymentalnej, w: tenże: Listy o estetycznym wychowaniu czlowieka i inne rozprawy, przeł. I. Krońska, Warszawa 1972; M. SIwIEC, Romantyczne koncepcje poezji. Poeta i Muza - relacja w stanie kryzysu, Kraków 2012. 
Szmydtowa Z., Norwid i Lenartowicz, „Przegląd Humanistyczny” 1973, nr 1.

Szulakiewicz M., Czas i to, co ludzkie. Szkice z chronozofii kultury, Toruń 2011.

Zaleski J. B., Wybór poezyj, oprac. B. Stelmaszczyk-Świątek, Wrocław-Łódź 1985, BN I, nr 30.

\title{
SPOTKANIA POETÓW W PRZESTRZENI I W SŁOWIE - O WIERSZACH NORWIDA DO JÓZEFA BOHDANA ZALESKIEGO
}

\begin{abstract}
Streszczenie
Tematem artykułu jest interpretacja dwóch wierszy Cypriana Norwida, których adresatem był Józef Bohdan Zaleski: Do Józefa Bohdana Zaleskiego w Rzymie 1847-o oraz Na przyjazd Teofila Lenartowicza do Fontainbleau. Ten drugi utwór ma charakter poetyckiego listu rekomendującego wizytę Lenartowicza u Zaleskich. Wiersze pozwalają na wgląd w relacje łączące trzech dziewiętnastowiecznych poetów. Artykuł wydobywa aspekty biograficzne, ale przede wszystkim odsłania, w jaki sposób autor wierszy postrzegał różnice między swoją wyobraźnią i postawą poetycką a poezją obu przyjaciół, i jak świadomość tej opozycji prowadziła do rozpoznawania cech własnej sytuacji na mapie polskiej poezji. Mikroanaliza wybranych motywów pozwala również wskazać pewne miejsca wspólne.
\end{abstract}

Słowa kluczowe: Norwid - Zaleski - Lenartowicz; dialogi poetów; liryka romantyczna, listy poetyckie.

\section{POETS MEETING IN SPACE AND WORD. ON NORWID'S POEMS ADDRESSED TO JÓZEF BOHDAN ZALESKI}

\begin{abstract}
This article offers an interpretation of two poems by Cyprian Norwid, which are addressed toJózef Bohdan Zaleski: "Do Józefa Bohdana Zaleskiego w Rzymie 1847-o"[To Józef Bohdan Zalski in Rome, in the year 1847] and "Na przyjazd Teofila Lenartowicza do Fontainbleau" [On the Arrival of Teofil Lenartowicz in Fontainbleau] The latter is a poetic letter that recommends to Lenartowiczthat he should pay a visit to the Zaleski family. These poems allow us a glimpse into the relationship between three nineteenth-century poets. The article elaborates on certain biographical elements but primarily reveals how the Norwid regarded the differences between his own imagination and poetic stance on the one hand and the works of his two friends on the other. Further, it shows how the awareness of this opposition led the poet to recognize aspects of his own place on the map of Polish poetry. Microanalysis of selected themes also facilitates indicating certain features they all share.
\end{abstract}

Translated by Grzegorz Czemiel

Key words: Cyprian Norwid; Józef Bohdan Zaleski; Teofil Lenartowicz; dialogues between poets; Romantic lyricism; poetic letters. 
Grażyna HaLkIEWICZ-SoJAK - prof. dr hab., badaczka i interpretatorka poezji XIX i XX wieku. W centrum jej zainteresowania znajduje się twórczość Norwida, której poświęciła liczne artykuły i książki autorskie (Byron w twórczości Norwida [1994], Wobec tajemnicy i prawdy. O Norwidowskich obrazach ,całości” [1998], Nawiazane ogniwo. Studia o poezji Cypriana Norwida i jej kontekstach [2010]). Pisała także o twórczości Zygmunta Krasińskiego, Juliusza Słowackiego, Adama Mickiewicza i dwudziestowiecznej recepcji poetyckiej emigracyjnego romantyzmu polskiego oraz dzieła Norwida (w twórczości Zbigniewa Herberta, Karola Wojtyły, Stanisława Balińskiego, Tadeusza Różewicza). Współredaguje rocznik „Studia Norwidiana", uczestnicy w pracach nad wydaniem krytycznym Dzieł wszystkich poety. Zawodowo związana z polonistyką Uniwersytetu Mikołaja Kopernika w Toruniu, członkini zarządu Toruńskiego Towarzystwa Naukowego. 